University of Nebraska - Lincoln

DigitalCommons@University of Nebraska - Lincoln

Journal of Women in Educational Leadership

Educational Administration, Department of

2020

The Life of Dr. Claire Owens

Kelley J. Rice

Follow this and additional works at: https://digitalcommons.unl.edu/jwel

Part of the Educational Administration and Supervision Commons

This Article is brought to you for free and open access by the Educational Administration, Department of at DigitalCommons@University of Nebraska - Lincoln. It has been accepted for inclusion in Journal of Women in Educational Leadership by an authorized administrator of DigitalCommons@University of Nebraska - Lincoln. 
Journal of Women in Educational Leadership, 2020

doi: 10.32873/unl.dc.jwel.196

http://digitalcommons.unl.edu/jwel/

ISSN 2379-2191

Journal of

Women in

Educational

Leadership

\title{
The Life of Dr. Claire Owens
}

\author{
Kelley J. Rice
}

In 1874, pioneers Lewis and Harriet Owens came to Fillmore County and homesteaded on the "east half of the northwest quarter of section 12 in the Madison Township". It was here, in a small sod house that their daughter, Claire Estelle Owens, was born on January 31, 1876.

At the age of eight Claire suffered a fall from a horse. Initially it was believed that Claire had not suffered any major injury but soon after her fall her teacher began to notice that Claire was struggling with reading. Initially her teacher believed that she may have a reading disability, however the fall had caused damage to her optic nerve and it wasn't long after this discovery that Claire was completely blind. Years later she would tell a news reporter that she had been blessed to have her sight for those eight years because it allowed her to envision color as others would describe their surroundings to her.

From a historical context, people who were blind were not considered as having much value because they would not be able to take care of themselves physically as well as financially. As perspective shifted,

1. Exeter Centennial Book Committee. They Called It Exeter. Exeter, NE: The Committee, 1979. 
society began to feel an obligation to care for the destitute and Alms houses were established.

It wasn't until 1784 that calligraphy professor, Valentin Hauy opened the National Institution for Blind Youth (later renamed the Royal Institute for Blind Youth) in Paris, France. Using his calligraphy skills, Hauy created a system that utilized embossed lettering that was raised so that his blind students could feel them and learn to read.

It wasn't until 1821 while Louis Braille was attending the Royal Institute that the current reading system for the blind was created. A soldier by the name of Charles Barbier visited the school and shared his invention called "night writing". ${ }^{2}$ This was a system of twelve dots used to silently communicate classified information on the battlefield. Unfortunately, the system was considered too complicated to understand and was abandoned by the military. Louis Braille understood the system and modified it to the six dots that makes up the system that is used today.

In New England the first school for the blind was opened in the United States in 1831 by Samuel Gridley and as the philosophy of education for the blind moved away from a charity to an "entitlement paid with tax dollars" 3 similar schools began to open across the country.

Unbeknownst to the Owen's family, Samuel Bacon, a blind man from Ohio, had lobbied the Nebraska Legislature and upon gaining their support, established a school for the blind in Nebraska City in 1875. The school was designed after two other schools Mr. Bacon had established in Illinois (1849) and Iowa (1852). Because the appropriations were minimal, Mr. Bacon used much of his own money to secure the school's location and develop curriculum. Claire was sixteen years old in 1892 when she finally convinced her family to allow her to attend the school that had grown from 17 students in 1877 to 105 in 1893.

Once in Nebraska City, Claire's "eagerness to learn was so great she often hid her books of Braille under her pillow to read and study at

2. Louis Braille Biography... Accessed April 27, 2018. http://braillebug.afb.org/louis braille bio.asp

3. Britannica, The Editors of Encyclopaedia. "Valentin Haüy." Encyclopædia Britannica. March 11, 2018. Accessed April 14, 2018. https://www.britannica.com/biography/ Valentin-Hauy 
night." 4 Her zealous desire to learn is said to have caused Claire to develop an illness that forced her to temporarily leave the school. Upon her return she was eager to resume her studies and Claire was able to complete twelve years of school in only six years' time. She spent two years completing her grade school studies and an additional four years completing her high school education. Claire graduated from the Nebraska School for the Blind in 1898 at the age of 22, with a major in English and music.

Claire had "a real horror about blind beggars" 5 when she was a small child. This fear propelled her to become independent and find a way to provide for herself. With this mindset Claire set out to find employment. In the late 180o's, music was not included in the public school curriculum but that didn't prevent Claire from petitioning the schools in Exeter and Fairmont to not only add music classes, but to allow a blind person to become their instructor. Claire stated "It never dawned on me that a blind person shouldn't teach music in the public schools so I convinced the authorities I should have the job." ${ }^{6}$ Claire became the first blind public school teacher in the United States in 1898 and taught vocal and instrumental lesson.

In addition to her love of music, Claire had a passion for travel and was never inhibited in exploring new locations. In 1902 Claire decided to travel to Oakland, Iowa to visit relatives. She enjoyed the area so much that she once again successfully petitioned two school systems in order to become their music teacher. Claire was hired by the Oakland and Macedonia schools but also traveled either by train or buggy to the towns of Hancock and Henderson to give private lessons.

Upon her return to Nebraska, Claire taught in Geneva and Exeter from 1907-1912. She then focused her expertise in Geneva full time and directed plays, operettas, and quartets. One of the quartets soon gained local notoriety performing locally as well as traveling to neighboring

4. Ibid., Exeter Centennial Book Committee.

5. Terrill, Dean. "Blindness Fails to Hinder Two Successful Careers by Woman." Lincoln Sunday Journal, September 17, 1961.

6. Billotte, Bill. "Woman, 76, Blind Since 8, Is Osteopath, Ex-Legislator.” World Herald (Omaha), 1952. 
towns and community events to show off their talents. The quartet Enece (pronounced Enna-see) was derived from group members Helen Edgecomb, Elsie Nichols, Bess Ertel, accompanist Bess Curtis, and Barbara Eckley who created the group using the first letter of their last names.

Even though Claire was passionate about teaching, she began to evaluate her career in 1917 and was concerned that her voice would not hold up to the rigors required of a music teacher. She later told a reporter "getting on toward forty I was afraid I'd lose my job and had to find something I could do with my hands."7 Despite resistance from many around her, she made the decision to go back to school to become a doctor of osteopathy stating that "other blind persons had succeeded at it."

Claire knew that going back to college full time would be expensive and limit her ability to work and be self-supporting. She also knew that she did not want to rely on others and be seen as a "beggar". With this mindset, Claire began to devise the perfect plan that would allow her to attend college and also manage to make a living. Upon enrolling at Still College of Osteopathy in Des Moines, Iowa she purchased a boarding house. The rent money earned from the boarding house was enough to cover her living expenses as well as her four years of tuition that totaled $\$ 5$,000.

Because the textbooks used during her studies were not available in Braille, Claire enlisted the help of her classmates to read to her. Although many people would find the task of retaining vast amounts of information through this method difficult, Claire had obviously mastered this technique. According to her transcripts, her coursework consisted of 36 classes over seven semesters. She received A's in most of her classes, receiving a 100\% in both physiology and dissection. Only five of her classes were below $85 \%$ with her lowest grades in obstetrics $(79 \%)$ and surgery $(80 \%)$.

Upon graduation, Dr. Owens made arrangement to move to Geneva and practice with Dr. Frank Bates. Dr. Bates, who was originally from South Dakota, was an alumni of Still College. He had given up his

7. Terrill, Dean. "Blindness Fails to Hinder Two Successful Careers by Woman.” Lincoln Sunday Journal, September 17, 1961.

8. Ibid., Terrill, Dean. 
profession in 1902 as a railway mail serviceman to attend the Still College of Osteopathy. After graduation, Dr. Bates moved to Geneva and had been practicing for approximately 15 years before Dr. Owens came to work with him. She practiced with Dr. Bates for two years and then, wanting to be independent, decided to open her own private practice. Dr. Owens moved back to her home town of Exeter and purchased a small home that would double as her office. She was extremely proud of her accomplishment and stated "I own my little house with its office here, and intend to keep practicing "til I die." 9

One of Dr. Owen's patients was Mrs. Eyvonne Johnson. Mrs. Johnson's family lived only two doors down from Dr. Owens and besides visiting regularly to socialize, the family members were also patients. Mrs. Johnson remembered one instance where the high school choir was getting ready to compete in a contest and she was suffering with a cold. The music teacher had informed the students that if they were not at practice they would not be allowed to travel and sing at the competition. It was at this point that Mrs. Johnson's mother called Dr. Owens. Dr. Owens saw Eyvonne immediately and was able to not only provide relief, but eliminate any symptoms she was having. Mrs. Johnson explained that Dr. Owens was "just fabulous" 10 and was always able to provide relief when she was ill.

Dr. Owens had a servant heart and continually integrated herself into the communities where she lived. Besides serving on the school board in both Geneva and Exeter, she was also the director of the local Red Cross for two years, served as president of the Women's Club for three years, and was on the board of directors of the Fillmore County Women's Club. Furthermore, she was an active member of the Exeter Commercial Club and taught a "Bible class" 11 and played the organ for her church.

However, her service did not stop at the local level. Dr. Owens became a charter member of the Nebraska Association of Workers for the Blind and throughout her lifetime held every office within the organization including the office of president for two years. She also became a member

9. Ibid., Terrill, Dean.

10. Johnson, Evyonne. Interview by author. March 2, 2018.

11. Ibid., Exeter Centennial Book Committee. 
of the American Association for the Blind and served as a director for ten years. During her involvement with the organization she attended eleven national conferences and became friends with Helen Keller. Besides being an advocate for the blind, professionally Dr. Owens was a member of the state and national Osteopathic Associations.

Intent on keeping up with current events, Dr. Owens relied on her "radio and talking books" 12 and hired a "reader to further her learning of national and international affairs."13 It was this passion that propelled her to serve two terms in the Nebraska Legislature.

During the 1931-1933 session, Dr. Owens introduced ten bills. These bills covered multiple issues, however House Roll NO.199 exemplified her compassion towards and dedication to women who didn't have a voice. The bill was introduced by J. Marrow and Dr. Owens to "provide for the appointment of women physicians for the care and supervision of the women insane in the state hospitals of the State of Nebraska." ${ }^{14}$ As a doctor and as a woman, Dr. Owens understood the emotions of being examined by a male, and for those who were mentally ill, this process could become even more traumatic. Even though this bill was sent to the state institution and then indefinitely postponed, it is an extraordinary example of the progressiveness of Dr. Owens and her belief in human rights.

According to the 1929 Nebraska Statutes section 71-2206, the "State Board of Examiners In the Basic Sciences" 15 was made up of five members who were appointed by the Department of Public Welfare. Appointees were selected based on "their knowledge of the basic sciences"16 but even with this knowledge, if they were "licensed to practice the healing

12. Ibid., Exeter Centennial Book Committee.

13. Ibid., Exeter Centennial Book Committee.

14. Nebraska. 1855. Nebraska House journal: reformatted from the original and including, Journal of the House of Representatives ... of the General Assembly of the Territory of Nebraska. https://dds.crl.edu/crldelivery/26790

15. Nebraska, and William C. Dorsey. 1930. Compiled statutes of Nebraska, 1929: comprising all the statutory law of a general nature in force, including the enactments of the forty-fifth biennial session of the Legislature which adjourned April 24, 1929, as well as of the forty-sixth session (special) which adjourned March 15, 1930. Lincoln, Neb: State Journal.

16. Ibid., Nebraska, and William C. Dorsey. 
arts or any branch thereof" 17 , they were not allowed to serve on the board. Dr. Owens did not agree with the division between medical practices and with the help of J. Marrow introduced House Roll NO. 411 in order to repeal the statute and allow those in the healing arts the right to serve on the board. The bill was first introduced on February 2, 1931 and was referred to the Department of Public Welfare twice before it was indefinitely postponed.

During the $47^{\text {th }}$ Legislative Session, all of the bills introduced by Dr. Owens were indefinitely postponed. Although this fact was most likely discouraging, she was not the type of person who would walk away from adversity. Her determination led her back to Lincoln in 1935 to again serve as a representative in the final session before Nebraska moved to a unicameral system. During the $50^{\text {th }}$ Legislative Session, Dr. Owens collaborated with other representatives and succeeded in having three bills approved by the Governor.

One of the successful bills was House Roll NO. 315 which proposed to amend the county tax levy and procedures so that money designated to help the blind would be more accessible. The 1929 statutes not only stated that an individual had to be a resident of the county for one year, but they must have resided in the state for five years before they were eligible to receive the benefits that were set at $\$ 300$ per year. These guidelines along with several others made the process difficult for the visually impaired to receive the help they deserved. This bill was first introduced on January 25, 1935 and after being referred to the Department of Welfare it was signed into law on April 22, 1935.

Throughout her lifetime, Dr. Owens would travel for speaking engagements and within Exeter there were several individuals besides her brother, who would drive her to these events. One story in particular comes from the daughter of Robert and Shirley Trauger. Mrs. Shirley Trauger was a dear family friend and would travel with Dr. Owens to her many engagements. On one particular occasion "mom was driving Dr. Owen's to one of her speaking engagements and it had been raining. After she finished speaking to the crowd and they were headed back to 
the car, Dr. Owen's reached up to adjust the hat she had been wearing. It was then that she noticed the feather that adorned her hat was drooping. From what my dad said, Dr. Owen's was not happy that she had spoken to a large group of people with a droopy feather. She told my mom to never let that happen again because it was embarrassing to her." ${ }^{18}$ From this story, one can surmise that Dr. Owens did not want anything to hinder people from hearing the message she was bringing. One can assume that there were many individuals who held prejudices against Dr. Owens just because of her blindness and presenting herself properly in public was a way to help bridge the divide.

Mrs. Trauger and her family became close friends of Dr. Owens. Dr. Owens was grateful for the way the family treated her and thanked them many times for treating her with dignity. It was because of this friendship that Dr. Owen willed her organ to the Traugers, with one stipulation. Because the organ originally belonged to Exeter's founder, Dr. H. G. Smith and was the oldest organ in Exeter, Dr. Owens stated in her will that the instrument could never be sold. The organ still sits in the Trauger home and although it is rarely played, it is still in working order, preserving the history of the town as well as Dr. Owens.

Dr. Owens remained political activity spanned 40 years after her service in the Legislature. She kept in contact with the Nebraska School for the Blind and was a "champion for the unsighted"19 making frequent trips to Lincoln to appear before the Legislature. She worked tirelessly to have the School for the Blind and the School for the Deaf become a part of the Department of Education. This dream was realized in 1959 when LB 281, sponsored by Senator George Syas from Omaha, was signed into law.

When Dr. Owens was not seeing patients or addressing the Legislature, one could find her traveling across the country taking in the sights. Throughout her lifetime she had traveled to 44 states and had visited Canada five times. She loved to "sight see" and upon her return, she would "dazzle listeners with her detailed descriptions." ${ }^{20}$ Those who 
knew Dr. Owens were amazed that a person without sight could "sight see", but when questioned she would exclaim "I just love it."

Dr. Owens "contributed more to the welfare of her fellow man then many sighted people." ${ }^{22}$ Her determination allowed her to manage her personal and business affairs, participate in civic organizations, and be a political activist. She had a passion to help others and at the age of 9o, was still practicing her profession and active in her community. Those who knew her saw her as a "remarkable woman" ${ }^{23}$ and would fill her mailbox with cards expressing their sentiments. When asked how she was able to accomplish so much, Dr. Owens simply stated "I guess I succeeded in doing just about everything I attempted because I was too ignorant to know that a blind person is not supposed to step around in the world." ${ }^{24}$

\section{References}

Allen, Tom. "Dr. Owens Featured in World Herald." World Herald (Omaha), 1963.

Billotte, Bill. "Woman, 76, Blind Since 8, Is Osteopath, Ex-Legislator." World Herald (Omaha), 1952.

Britannica, The Editors of Encyclopaedia. "Valentin Haüy." Encyclopædia

Britannica. March 11, 2018. Accessed April 14, 2018. https://www.

britannica.com/biography/Valentin-Hauy.

"Dr. Claire Owens is Named to 1975 Womans Hall of Fame." Unknown, 1975.

"Dr. Claire Owens, 9o, Dies; Former Legislator, Teacher." Unknown, November 1966.

"Dr. Owens Will Filed For Probate." Unknown, November 1966.

Exeter Centennial Book Committee. They Called It Exeter. Exeter, NE: The Committee, 1979.

"History of Blindness." History of Blindness | American Action Fund. Accessed April 14, 2018. https://actionfund.org/history-blindness.

21. Ibid., Terrill, Dean

22. Ibid., Exeter Centennial Book Committee

23. "This Is Your Life." Unknown, November 1966.

24. Ibid., Billotte, Bill 
Johnson, Evyonne. Interview by author. March 2, 2018.

Louis Braille Biography... Accessed April 27, 2018. http://braillebug.afb.org/ louis braille bio.asp

McKee, Jim. "Jim McKee: History of Nebraska School for the Blind.” Lincoln Journal Star,

April 14, 2013. Accessed October 6, 2017. http://journalstar.com/news/local/ jim-mckee-history-of-nebraska-school-for-the-blind/article aebozfddc4a3-527f-8ec2-b97ageg5212b.html

Nebraska, and William C. Dorsey. 1930. Compiled statutes of Nebraska, 1929: comprising all the statutory law of a general nature in force, including the enactments of the forty-fifth biennial session of the Legislature which adjourned April 24, 1929, as well as of the forty-sixth session (special) which adjourned March 15, 1930. Lincoln, Neb: State Journal.

Terrill, Dean. "Blindness Fails to Hinder Two Successful Careers by Woman." Lincoln Sunday Journal, September 17, 1961.

“This Is Your Life.” Unknown, November 1966. 